Research Article

\title{
Expression Collagen I and III in Anterior Vaginal Women with and without Pelvic Organ Prolapse
}

\author{
Ekspresi Kolagen I dan III di Dinding Vagina pada Perempuan \\ dengan dan tanpa Prolaps Organ Panggul
}

\author{
Basyar, Trika Irianta, Syahrul Rauf \\ Department of Obstetrics and Gynecology \\ Faculty of Medicine University of Hasanuddin/ \\ Dr. Wahidin Sudiro Husodo Hospital \\ Makassar
}

\begin{abstract}
Objective: To find out the expression of collagen I and III in the anterior vaginal wall of women with and without pelvic organ prolapse (POP).

Method: The research was a cross sectional study, conducted in Dr. Wahidin Sudiro Husodo hospital and its networks from January 1, 2011 to April 1, 2012. The case group consisted of 35 women with POP level III and IV. The control group consisted of 35 women without POP. The expression of collagen I and III were examined by immunohistochemical test with the staining of antibody of collagen I (mouse monoclonal collagen Iab 90395) and the antibody collagen III (Mu 167 4i). The data was then analyzed by using a computer statistic program with a significance level of 0.05 .
\end{abstract}

Result: It was found that in the group of women with POP, there were 28 cases of expression collagen III (84\%), which is significantly higher than in women without POP, found in only 20 cases (58.8\%), with $\mathrm{p}=0.02$. Meanwhile, in the group of POP, $9.1 \%$ of subjects showed moderate expression of collagen I, significantly less compared to the expression in the control group (35.3\%), with $\mathrm{p}=0.007$. For the ratio of collagen I and III, the result was weak in women with POP (58.5\%) while in the control group, the result was high (85.7\%).

Conclusion: In terms of collagen I and III expression, there was no significant difference between the two groups.

[Indones J Obstet Gynecol 2014; 2: 87-90]

Keywords: collagen I, collagen III, pelvic organ prolapse, vaginal wall

\begin{abstract}
Abstrak
Tujuan: Mengetahui ekspresi kolagen I dan III di dinding vagina anterior pada perempuan dengan prolapse organ panggul (POP) dan tanpa prolapse organ panggul (POP).

Metode: Penelitian bertempat di BLU RS dr. Wahidin Sudiro Husodo Makassar dan jejaringnya. Rancangan penelitian adalah studi potong lintang. Sampel penelitian terdiri atas 35 perempuan dengan POP tingkat III dan IV yang diambil periode 1 Januari 2011 - 1 April 2012, dan sebagai kontrol adalah 35 perempuan tanpa POP. Ekspresi kolagen I dan III dinilai dengan pemeriksaan imunohistokimia menggunakan pewarnaan antibodi kolagen I (mouse monoclonal collagen I ab 90395) dan antibodi kolagen III ( Mu 167 4i). Data diolah dengan menggunakan program komputer statistik. Tingkat signifikansi yang digunakan adalah 0,05.
\end{abstract}

Hasil: Pada kelompok POP ekspresi kolagen III sebanyak 28 kasus (84\%) lebih tinggi daripada kelompok tanpa POP sebanyak 20 kasus $(58,8 \%)$ dengan nilai $p=0,02$. Sedangkan ekspresi kolagen I didapatkan pada kelompok POP yang terekspresi moderat sebanyak 9,1\% dibandingkan kontrol sebanyak 35,3\% dengan nilai $p=0,007$. Untuk rasio kolagen I/III diperoleh hasil yang rendah pada sampel (58,5\%) sedangkan hasil yang tinggi pada kontrol $(85,7 \%)$ dengan nilai $p=0,00$.

Kesimpulan: Analisis faktor risiko perempuan dengan POP dan tanpa POP untuk kolagen I dan III tidak tampak perbedaan yang bermakna pada kedua kelompok.

[Maj Obstet Ginekol Indones 2014; 2: 87-90]

Kata kunci: dinding vagina, kolagen I, kolagen III, POP

Correspondence: Basyar. Jln. Teuku Umar 12 Ir 3 no 40, Makassar. Telephone: 081355125596. Email:risnarjb@yahoo.com

\section{INTRODUCTION}

Pelvic organ prolapse (POP) is a morbidity that affects a woman's quality of life. The prevalence is higher in developed countries, even though the etiologies are different. ${ }^{1}$

One important character of POP is failure of levator ani muscle to function normally ${ }^{2}$, but the exact pathogenesis is still unknown. ${ }^{3}$ Fascia and connective tissue of the pelvic floor possibly lose its strength as the result of aging process and the lost of neuroendocrine signal. ${ }^{4}$
The varying strength of pelvic floor ligament and fascia between every woman is one of the most important factor in the pathogenesis of POP. Collagen is the main component of the pelvic floor connective tissue. Takano et al reported qualitative and quantitative change of collagen in patients with genital prolapse and stress incontinence. ${ }^{5}$

Until now, the relation between collagen and POP is still being studied. It was reported that there was a difference on the amount of collagen type I 
in women with and without POP. ${ }^{6}$ But, Norton et al reported that the type I collagen fibrin was shorter, thinner, and less abundant in women without POP. Liapis et al reported that in women with and without POP, the amount of collagen had no difference. ${ }^{8}$ Ewies et al reported that type III collagen was found to be increased in the tissue of women with POP and this was supported by several other studies as well, though the results differed. ${ }^{6}$ Several other studies also found a decrease in total collagen in women with POP. ${ }^{9}$

Several researchers believed that a disturbance in vesico or in uterosacral ligament could cause a defect in genitourinary supporting structure. Several studies had focused on the role of connective tissue and collagen in POP of vaginal posterior wall. ${ }^{7}$ Delancey proposed that vaginal epithelial, collagen layer and deeper smooth muscle layer give support along side the vaginal wall and possibly is more vulnerable to the secondary effect of prolapse.

Overall, the changes in the expression of collagen type I and III, the decrease in elastin's immune reactivity, and the increasing tenascin synthesis could explain the loss of the connective tissue's supporting function. These data showed the possible role of those protein in the pathogenesis of POP and the concept of its therapy. The fact that abnormalities in both structural and repair mechanism of the connective tissue could be a predisposing factor for women suffering POP. Study on this subject has never been performed in Indonesia. Thus we would like to perform research on this matter.

This study was aimed to show that the expression of collagen type I and III in women with POP could contribute to understand the etiology and pathophysiology of prolapse. This study examined the expression of collagen type I and III in the vaginal wall of normal women and women with POP stage III-IV and analyzed the risk factor of POP.

\section{METHOD}

The research was a cross sectional study, conducted in Dr. Wahidin Sudiro Husodo hospital and its networks from January 1, 2011 to April 1, 2012. The case group consisted of 35 women with POP level III and IV. The control group consisted of 35 women without POP. The expression of collagen I and III were examined by immunohistochemical test with the staining of antibody of collagen I (mouse monoclonal collagen I ab 90395) and the antibody collagen III (Mu 167 4i). The data was then analyzed by using a computer statistic program with a significance level of 0.05 .

\section{RESULTS}

We analyzed the anterior vaginal wall of 40 women during the period of January 1, 2011 - April 1, 2012 at BLU RS dr. Wahidin Sudiro Husodo Makassar and its network. Thirty five women with POP were taken as the sample group and the control group were 35 women without POP.

Table 1. The Relation of Collagen Type I Expression with Pelvic Organ Prolapse.

\begin{tabular}{lccccc}
\hline \hline \multirow{2}{*}{$\begin{array}{c}\text { Collagen } \\
\text { type I } \\
\text { expression }\end{array}$} & \multicolumn{4}{c}{ GOP } & \multicolumn{2}{c}{ without POP } & p \\
\cline { 2 - 4 } & Proup & \\
\hline- & 21 & 63.6 & 9 & 26.5 & \\
+ & 7 & 21.2 & 8 & 23.5 & \\
++ & 3 & 9.1 & 12 & 35.3 & 0.007 \\
+++ & 2 & 6.1 & 5 & 14.7 & \\
\hline \hline
\end{tabular}

Table 1 shows the expression of collagen I in patients with pelvic organ prolapse where the majority of study group showed negative expression with $21(63.6 \%)$, while in the control group was moderate (++) 12 (35.3\%). The moderate and powerful expression of collagen type I was more commonly found in the group without pelvic organ prolapse compared to pelvic organ prolapse group with $\mathrm{p}=0.007$.

Table 2. The Relation of Collagen Type III Expression with Pelvic Organ Prolapse.

\begin{tabular}{lccccc}
\hline \hline \multirow{2}{*}{$\begin{array}{c}\text { Collagen } \\
\text { type III } \\
\text { expression }\end{array}$} & \multicolumn{4}{c}{ POP } & \multicolumn{2}{c}{ without POP } & p \\
\cline { 2 - 4 } & $\mathbf{n}$ & $\%$ & $\mathbf{n}$ & $\%$ & \\
\hline- & 0 & 0 & 0 & 0 & \\
+ & 0 & 0 & 3 & 8.8 & \\
++ & 5 & 15.2 & 11 & 32.4 & 0.02 \\
+++ & 28 & 84.8 & 20 & 58.8 & \\
\hline \hline
\end{tabular}

Table 2 shows that the strong expression of collagen type III was more commonly found in the group with POP (84.8\%) compared to the group without POP (58.8\%). 
From the result of chi square analysis, it was shown that there was a significant difference of collagen type III expression between the group with POP and the group without POP $(\mathrm{p}=0.02)$.

Table 3. Collagen I and III expression Ratio in POP and without POP

\begin{tabular}{lccccc}
\hline \hline \multirow{2}{*}{$\begin{array}{c}\text { Collagen } \\
\text { I/III } \\
\text { ratio }\end{array}$} & \multicolumn{4}{c}{ GOP } & \multicolumn{2}{c}{ without POP } & & $\mathbf{p}$ \\
\cline { 2 - 5 } & $\mathbf{n}$ & $\%$ & $\mathbf{n}$ & $\%$ & \\
\cline { 2 - 5 } & 31 & 58.5 & 22 & 41.5 & \\
Low & 2 & 14.3 & 12 & 85.7 & \\
High & & & & & \\
\hline \hline
\end{tabular}

Table 3 showed that the low ratio of collagen I/III was mostly found in group with POP (58.5\%), while the high ratio was more common in non-POP group $(85.7 \%)$. The result of statistical analysis showed a significant difference of collagen I/III expression ratio between the group with POP and without POP with $\mathrm{p}<0.000$ (Yate's correction, $\mathrm{p}$ $<0.001$ ).

\section{DISCUSSION}

This study showed that the expression of collagen type I was higher in women without POP while the expression of collagen type III was higher in women with POP. In women with POP, it is more common to find low ratio of collagen type I/III expression. Thus, it could be concluded that the change in the expression of type I and III collagen in women with POP was responsible in the weakening of the tissue.

The cells in the connective tissue synthesize various component of extracellular matrix, which not only support a certain biomechanical properties, but also the regulation of cellular functions. This gives the impression that the disturbance in the supportive structure of the pelvis could be caused by intrinsic abnormality of collagen synthesis or the imbalance between the synthesis and degradation. ${ }^{1}$

Type I and III collagen have their own physical advantages and their proportion will relatively affect the function of the tissue. It is known that type I collagen give a great mechanical strength to connective tissue, while type III collagen plays a role in elasticity of the connective tissue. Type I collagen is the most abundant collagen in the skin, tendon, ligament, and bone, making up almost $80-99 \%$ of total collagen in the body. Type III collagen could also be found in various part, but the ratio differs in each tissue. ${ }^{10}$ Thus, it is agreed that a high ratio of type I/III collagen shows a great tissue strength, while a low ratio indicates a weakness of the tissue. $^{1}$

The analysis of risk factor of POP did not show any significant difference in the two groups. Swift $S$ et al found that POP stage I and II were mostly found in young women, while stage III and IV was more common in women over 40 years old and the prevalence increase as much as $21 \%$ in women over 70 years old. ${ }^{10}$ Chen GD et al noted that age is a risk factor in the development of POP. It has been said that the complaint of pelvic disfunction will increase as the age advances. This hypothesis is the secondary cause from various factors in it, such as the decrease of estrogen in postmenopausal period. Chen et al also found an estrogen receptor in the vaginal wall and sacrouterine ligament in premenopausal women, but those will decrease when the women reached post menopausal period. ${ }^{11}$

Chiaffarino $\mathrm{F}$ et al found that women with high parity had a higher risk of developing genital prolapse (OR 2.6), compared to women who never gave birth. The OR was 3 for women who gave birth once, and increase to 4.5 in women who gave birth more than two times. This affect the connective tissue in the pelvic floor and could cause a damage in the pudendal nerve in all women giving birth, in which the delivery process could cause the pelvic muscle to loosen up. The OR was 0.9 for women giving birth to baby weighing 3500 gram or more. ${ }^{12}$

Hendrix SL concluded that obesity also had a strong influence on the pelvic floor function. Women's Health Initiative (WHI) found that women with Body Mass Index (BMI) of more than 25-30 $\mathrm{kg} / \mathrm{m}^{2}$ had a $31 \%$ chance to develop uterine prolaps, $38 \%$ for rectocele, and $38 \%$ for sistocele. this percentage will only increase as the BMI increases. $^{13}$

\section{CONCLUSION}

In women with POP, type I collagen expression level is lower. We hope that with this study, the incidence of POP will decrease by giving a consultation to patient about the risk factor of POP in order to serve a holistical approach. Further studies 
on the expression of type $\mathrm{V}$ collagen in the vaginal wall is still needed to understand the complete role of collagen in the occurence of POP.

\section{REFERENCES}

1. Mac Lennan A. The descent of woman. Climacteric. 2000: 222-6.

2. Boreham MK, Wai C, Miller R, Schaffer J, Word R. Morphometric analysis of smooth muscle in the anterior vaginal wall of women with pelvic organ prolaps. Am J Obstet Gynecol. 2002; 187: 56-63.

3. Bidmead JLD. Pelvic floor changes in the older woman. Bri J Urol. 1998; 82 (Suppl. 1): 18-25.

4. Smith AR, Hosker G and Warrell D. The role of partial denervation of the pelvic floor in the aetiology of genitourinary prolaps and stress incontinence of urine: A neurophysiological study. Bri Obstet Gynaecol. 1989; 96: 24-8.

5. Takano CC, Girao MJBC, Sartori MGF, Castro RA, Arruda RM, Simoes MJ, Baracat EC and De Lima GR. Analysis of collagen in parametrium and vaginal apex of women with and without uterine prolapse. Int Urogynecol J. 2002; 13: 342-5.

6. Ewies AA, Al-Azzawi $\mathrm{F}$ and Thompson J. Changes in extracellular matrix proteins in the cardinal ligaments of postmenopausal women with or without prolapsed: a computerized immunohistophometric analysis. Eur Soc Hum Reprod Embryol. 2003; 18: 2185-95.
7. Norton P, Boyd C and Deak S. Collagen synthesis in women with genital prolapse or stress urinary incontinence. Neurol Urodyn. 1992; 11: 300-1.

8. Liapis A, Bakas P, Pavitri A, Frangos-Plemenus M, Arnoyonnaki N, Creatsas G. Change in collagen type III in female patient with genuine stress incontinence and pelvic floor prolapse. Eur J Obstet Gynecol Reprod Biol. 2001; 97: 76-9.

9. Stanosz S, Wilanowski K, Zehrowski W, Hadjaz P, Kosciuszkiewicz D. Certain biochemical markers in women with abnormal status of reproductive system. Gynecol Pol. 1995; 66: 18-22.

10. Swift S, Woodman P, O’Boyle A, Kahn M, Valley M, Bland D, Wang W and Schaffer J. Pelvic Organ Support Study (POSST): The distribution, clinical definition, and epidemiologic condition of pelvic organ support defects. Am J Obstet Gynecol. 2009; 192: 795-806.

11. Chen GD. Pelvic floor dysfunction in aging women. Taiwan J Obstet Gynecol. 2007; 46: 374-8.

12. Chiaffarino F, Chatenoud L, Dindelli M, Meschia M, Buonaguidi A, Amicarelli F, Surace M, Bertola E, Di Cintio E and Parazzini F. Reproductive factors, family history, occupation and risk of urogenital prolapse. Eur Obstet Gynecol J. 1999; 82: 63-7.

13. Hendrix SL, Clark A, Nygaard I, Aragaki A, Barnabei V, McTiernan. Pelvic organ prolapse in the women's health initiative. Gravity and gravidity. Am J Obstet Gynecol. 2002; 195: 23-8. 